\title{
The effects of fiscal policy in great recession by using panel smooth transition regression (PSTR): Evidence from emerging market
}

\author{
Amira Majoul ${ }^{1}$, Olfa Manai Daboussi ${ }^{2}$ \\ ${ }^{1}$ Applied Quantitative Analysis, Unit (UAQUAP), Tunisia ISG and GATE (UMR 5824 CNRS) \\ ${ }^{2}$ Higher Institute of Management of Tunis, University of Tunis, Tunisia \\ Email address: \\ majoul_amira@hotmail.com (A. Majoul),manaolfa@yahoo.com (O. M. Daboussi)
}

\section{To cite this article:}

Amira Majoul, Olfa Manai Daboussi. The Effects of Fiscal Policy in Great Recession by using Panel Smooth Transition Regression (PSTR): Evidence from Emerging Market. International Journal of Business and Economics Research.

Vol. 3, No. 2, 2014, pp. 99-107. doi: 10.11648/j.ijber.20140302.17

\begin{abstract}
This article examines the effect of fiscal policy on economic growth in emerging countries during periods of economic instability. This work aimed to determine whether emerging countries are able to adopt countercyclical fiscal policies to mitigate the impact from outside. Our study used a new approach developed by González and al. (2005), the (PSTR) model. This model has been studied in 23 emerging countries grouped into four regions: Latin America, Emerging Europe, Asia and Africa and covers the period 1990-2012. Our research will focus on the effect of fiscal policy in emerging countries on their economic growth during periods of instability. This model confirmed the non-linear relationship between fiscal policy and activity in these countries. Indeed, it can highlight the asymmetric effect of fiscal policy on activity distinguishing between two regimes. Our results show that in an unsustainable fiscal situation, the pro-cyclical fiscal policy is a solution to avoid the higher cost of debt and during the crisis a strong fiscal position is fundamental to ensuring macroeconomic stability.
\end{abstract}

Keywords: Great Recession, Fiscal Policy, Smooth Transition Models, Emerging Markets

\section{Introduction}

During the $21^{\text {th }}$ century and throughout the world, the subprime crisis had led to macroeconomic instability and major social problems, which pose serious difficulties for economic policymakers. Many observers economists have argued that the extent and severity of this recession comparable to the Great Depression of the 30s. The worldwide recession has been accompanied by a slumping demand, leading to a sharp decline in exports in many countries.

In this respect, economic policymakers must detect any emergency measures to be adopted in order to curb the negative effects of the crisis on the global economy. To this end, they have two main levers of economic policy: fiscal policy and monetary policy. Given that interest rates are already low for most countries, monetary policy has limited effectiveness to support the recovery. This gives fiscal policy a very important role. The challenge then is to achieve an active fiscal policy without creating a situation of unsustainability of debt that could lead to adverse effects of fiscal policy. For this reason, attention to the role of financial aid in macroeconomic stabilization, especially in emerging countries, has been renewed.

During the last decades, several empirical studies have investigated the interdependence and transmission mechanisms of fiscal policy on economic activity.

In this context, Blanchard and Perotti (2002) use the structural VAR model to study the effect of fiscal policy on output and private consumption in the United States. They show that the expansionary fiscal policy positively affects the output with a multiplier which varies between 0.66 and 0.9 . However, this effect declined with time. They also show that this policy has a positive effect on private consumption and a negative effect on private investment. In a recent study Kirchner and al. (2010) uses the same model to show the effectiveness of public spending in the short term in the Euro Area for the period 1980-2008.

Contrary to what these researchers demonstrated, Giavazzi and al (2005) show empirically that budget expenditure does not always have a positive effect on the activity. In other words, there is a non-Keynesian effect. 
They show that when public debt is high, the effect of expansionary fiscal policy on activity is similar to a restrictive fiscal policy. In other words, an expansionary fiscal policy can have negative effects on economic activity.

A reduced number of works has studied the reaction of fiscal policy during periods of financial stress, and the effects vary according to the period (crisis versus non-crisis). May be mentioned in this context the study of Bouthevillain and Dufrenot (2010), which using the model of Markov Switch to varied probability (MSTVP), showed that public spending in France have a stronger impact during crises. The authors also showed that during the crisis, the spending multiplier is greater than the revenue multiplier. By against, Afonso and al. (2010), using panel data on OECD countries and non-OECD covering the period 1981-2007 show that spending during crises and regular periods have the same impact.

In fact, fiscal policy in emerging markets is facing several challenges. However, despite their importance, the literature on fiscal policy in emerging countries is very limited. In this context, Baldacci and al (2008) studied the effect of fiscal policy on emerging and developed economies during periods of banking crises during the period 1980-2012. They show that fiscal responses were significant for all times of crisis. They also show that these policies are limited in countries that suffer from significant budget constraints.

Hutchison and al. (2010) examine the effect of fiscal and monetary policy on the growth rate during financial crises characterized by a "sudden stops" in net capital inflows in developing and emerging market economies. They use a baseline empirical model to control for the various determinants of output losses during sudden stops crisis. They also show the importance of using expansionary fiscal policy while the effect of monetary policy is neutral.

Gavin and al. (1996), Gavin and Perotti (1997) studied the effect of fiscal policy in Latin America. They suggest that fiscal policy is pro-cyclical, particularly during periods of low growth.

Recently Jawadi and al. (2011) study the impact of the impact of fiscal policy (Brazil, China, India and Russia) using a set of SVAR models. They find that spending shocks have Keynesian effects while shocks revenue such as tax increases negatively affects the output. In other words, these results challenge the idea that emerging markets are not able to adopt counter-cyclical policies to stabilize their economies.

The core issue, which occupies an important place in literature, is whether emerging countries have responded with counter-cyclical policies or not. The theoretical and empirical literature has identified a number of factors suggesting that emerging countries have difficulties to conduct countercyclical fiscal policies. Some believe that most emerging countries suffer from limited capacity strengthening their institutions and accumulation of budget deficits. These last two characteristics can threaten private spending and market confidence. In this respect during periods of financial instability, the fiscal imbalance can erode the sustainability of public debt and reduce investment.

The institutional factors may also play an important role in explaining this pro-cyclicality. Indeed, the budgetary rigidity, the volatility of tax revenue and fiscal decentralization impairs the ability of government to restrict their spending during booms for use in times of recession.

Moreover, few studies have analyzed the effect of fiscal policy on activity in general or in periods of crisis despite its importance. As well as the period of crisis is short and the econometric methods are insufficient to detect the effect of the fiscal policy on economic activity.

Most empirical studies have examined the effect of fiscal policy on activity in general or in times of crisis are based on panel models or on SVAR models. However, these two models do not take into account the nonlinear character of fiscal policy. To overcome this limitation, it is necessary to use Panel Smooth Transition Regression (PSTR). This econometric model provides advantage to generate different dynamics depending on the phase of the cycle. Based on these results, we try to establish empirical studies that allow providing robust answers to show how emerging economies can face challenges to conduct countercyclical fiscal policies.

The aim of this paper is to evaluate the effectiveness of fiscal policy in emerging countries in periods of crisis. However, we investigate the effect of fiscal policy on economic activity, distinguishing between periods of recession and normal periods or expansion. Thus, we hope to achieve two goals in this work: one is to contribute to the economic literature on the topic; and the other is to have a more reliable yardstick available in order to explore the nonlinear effect of fiscal policy in emerging countries on the activity during periods of crisis.

We structure the paper such that section two present empirical analysis and introduces the dataset. In section three gives the estimations results. Section four is devoted to the discussion. Finally, we give the conclusion. The paper has additional tables in the appendices.

\section{Empirical Study}

We study the nonlinearity in the relationship between the budget deficit and economic activity using a model of regime change. Specifically, we use a new empirical approach, the threshold model with smooth transition panel: the (PSTR) model recently developed by González and al. (2005) and by Fok and al. (2004).

The advantage of this model is that it assumes that the transition from one regime to the other is based on a variable threshold and to generate different dynamics depending on the phase of the cycle.

\subsection{The Model}

With the aim to estimate the nonlinear effect of fiscal policy on economic activity, we use the (PSTR) model introduced by González and al. (2005). The (PSTR) model 
with two extreme regimes and fixed effect is defined as follows:

$$
G A P_{i t}=\alpha_{i}+\left(\beta_{o} X_{i t}\right)+\left(\beta_{1} X_{i t}\right) * g\left(q_{i t}, \gamma, c\right)+u_{i t}
$$

With $\mathrm{i}=1, \ldots, \mathrm{N}$ represents the cross-section and $\mathrm{t}=1, \ldots \ldots, \mathrm{T}$ is time dimensions of the panel. The dependent variable $\mathrm{GAP}_{\text {it }}$ is the output variable GAP which is considered a proxy of the activity. The vector $X_{i t}$ is a k-dimensional vector of time-varying exogenous variables includes a set of exogenous variables whose fiscal variable, $\alpha_{i}$ presents the individual fixed effect and $u_{i t}$ are the errors. The transition function $g\left(q_{i t}, \gamma, c\right)$ is a continuous function of the observed variable $q_{i t}$ and takes values between 0 and 1 and the extreme values and associated coefficients $\beta_{0}$ and $\beta_{1}$.

According González and al. (2005), we consider the following transition function:

$$
g\left(q_{i t}, \gamma, c\right)=\frac{1}{1+\mathrm{e} \chi \mathrm{p}\left(-\gamma\left(q_{i t}-c\right)\right)}, \gamma>0
$$

With $q_{i t}$ the variable threshold, c le parameter threshold, $\gamma>0$ the parameter that determines the speed of transition from one regime to another.

When $\gamma \rightarrow \infty$, the transition function becomes an indicator function I $\left[q_{i t}>c\right]$ which is taken as 1 if $q_{i t}>c$. In that case the (PSTR) model in (1) reduces to the two-regime panel threshold model of Hansen (1999). In this case, the effect of fiscal policy on output is given by $\beta_{0}$ if $\mathrm{q}_{\mathrm{it}}<\mathrm{c}$ and $\beta_{0}+\beta_{1}$ if $\mathrm{q}_{\mathrm{it}}>\mathrm{c}$. When $\gamma \rightarrow 0$, the transition function becomes constant, in which case the model collapses into a homogenous or linear panel regression model with fixed effects.

$$
G A P_{i t}=\alpha_{i}+\left(\beta_{0} X_{i t}\right) * g_{1}\left(q_{i t}, \gamma_{1}, c_{1}\right)+\left(\theta_{1} \beta_{2} X_{i t}\right) * g_{2}\left(q_{i t}, \gamma_{2}, c_{2}\right)+u_{i t}
$$

Substituting this equation by its first-order Taylor expansion around $\gamma_{2}$ the model becomes:

$$
G A P_{i t}=\alpha_{i}+\left(\beta_{0} X_{i t}\right)+\left(\beta_{1} X_{i t}\right) * g_{1}\left(q_{i t}, \gamma_{1}, c_{1}\right)+\left(X_{i t}\right) * q_{1}+u *_{i t}
$$

In this case, the null hypothesis of non-linearity is not defined as $\mathrm{H}_{0}: \theta 1=0$. LM, LM $\mathrm{FM}_{\mathrm{F}}$ and LR test are recalculated. If they are rejected, the model is estimated with three regimes. The test procedure continues until the acceptance of $\mathrm{H}_{0}$.

To estimate the model parameters $\left(\beta_{0}, \beta_{1}, \gamma, c\right)$, following González and al. (2005) and Fouquau and al. (2007), we use the method of nonlinear least squares.

To do this, we begin first by eliminating the individual effect and, by removing specific individual averages, which means that the average is subtracted for each variable and for each individual. This step is standard in linear models (Within transformation). However, it requires a more careful treatment in the context of threshold models.

Then, we apply the nonlinear least squares these transformed data. This method is equivalent to the maximum likelihood estimation with the error terms that are normally distributed. Our model can be rewritten as follows:

$$
G A P_{i t}=\alpha_{i}+\beta^{\prime} X_{i t}(\gamma, c)+u_{i t}
$$

The average individual is as follows:

$$
\overline{G A P_{l}}=\alpha_{i}+\beta_{0} \bar{X}_{i}+\beta_{1} \overline{\overline{W_{l}}(\gamma, c)}+\bar{u}_{i}
$$

Where $\overline{G A P_{l}}, \bar{X}_{i}, \bar{w}_{i}, \bar{u}_{i}$ represents the average individual.

Subtracting this equation from the first, we get:

$$
\widehat{G A P_{l t}}=\beta^{\prime} \widehat{X_{l t}}(\gamma, c)+\widehat{u_{l t}}
$$

With $\quad \widehat{G A P_{l t}}=G A P_{i t}-\overline{G A P_{l}} \quad, \quad \widehat{X_{l t}}(\gamma, c)=\left(X_{i t}-\right.$ $\left.\bar{X}_{i}, X_{i t} g\left(X_{i t}, \gamma, c\right)-\bar{W}_{l}(\gamma, c)\right)$ Where: $\widehat{u_{l t}}=u_{i t}-\bar{u}_{i}$ and $\bar{W}_{l}(\gamma, c)=\mathrm{T}^{-1} \sum_{t=1}^{T} X_{i t} g\left(X_{i t}, \gamma, c\right)$

Accordingly, the transformed vector $\widehat{X_{l t}}(\gamma, c)$ depends on $\gamma$ and c for levels and the average individual. For this reason, $\widehat{X_{l t}}(\gamma, c)$ is calculated for each iteration in optimization of nonlinear least square. 


\subsection{Econometric Methodology and Data}

\subsubsection{Evaluate Model}

The choice of this model is based on the intuition that, during periods of economic slowdown, the effect of fiscal policy on economic activity differs to that observed during normal periods. Indeed, its impact varies based on factors beyond the direct control of governments such as liquidity constraints, the size of the shocks, the macroeconomic environment and the state of public finances. Therefore, fiscal policy depends on the economic and political circumstances, are better studied using econometric models can generate different dynamics depending on the phase of the cycle. In this respect a simple linear model can not meet these expectations since it implies symmetry throughout the cycle. For against, the model (PSTR) allows to highlight the potentially asymmetric effect of fiscal policy on activity by distinguishing two regimes. This model also allows capturing structural breaks from an exogenous variable.

\subsubsection{Data and Estimates}

By using the model (PSTR), we test the effect of fiscal policy on economic activity, distinguishing between periods of recession and normal periods or expansion.

We use this model on annual data for 23 emerging countries grouped into 4 regions for the period 1990-2012. For robustness reasons, different country samples are being used. The first country sample includes 7 countries in Latin America. The second sample includes 3 African countries. The third sample 8 Asian countries and the last sample includes 5 countries in emerging Europe (see table A in appendix).

In this regard, we use the output variable GAP as a dependent variable representing economic activity. Fiscal variable (the structural budget balance) and a set of control variables selected by relying on the related literature are considered as independent variables. More specifically, five domestic variables are used: the variable foreign currency debt of the private sector as a percentage of GDP, trade openness ratio, a dummy variable taking the value 1 in the presence of stopping capital and zero otherwise, the rate inflation, the rate of credit growth as a percentage of GDP, And two variables reference the terms of the international environment: the U.S. interest rate and the American output gap. We do not limit ourselves to a single threshold variable since it takes into account three variables thresholds: the output GAP delayed the public debt to GDP ratio and the variation rate of capital inflows. We use the database the IMF (International Financial Statistics (IFS)). For missing data we used the annual base given by the World Bank, Honig (2006), Reinhart, Camen M. and Rogoff (2010), and Lane and Milesi-Ferretti (2007).

\section{Estimation Results}

\subsection{Case of Asia}

From Table B (in appendix), the null hypothesis of linearity between fiscal policy and activity is not rejected at the $5 \%$ level for the output gap variable and $10 \%$ for variable rate public debt. This result confirms that there is a non-linear relationship between fiscal policy and economic activity. Regarding the fiscal policy variable, the table shows that the phases of the cycle also affect the influence of fiscal policy on economic activity. The result is consistent with economic intuition. Indeed, in the regime of recession when the output gap is less than $1.4 \%$, the coefficient of fiscal policy is positive and statistically significant. This result suggests that fiscal policy is pro-cyclical.

However, the state does not intervene to stimulate economic growth in a recession. This result confirms the study Aghevli (1999) shows that during the Asian crisis, fiscal policy in these countries were prudent, they favored monetary policy to boost economic activity. In this respect, the monetary authorities have lowered interest rates and let the currency depreciate. By against, beyond the critical regime, the coefficient becomes negative and significant. This result shows that in this case the expansionary fiscal policy is recommended.

\subsection{Case of Africa}

Table C (in appendix) shows that the non-linearity is rejected with the three variables of transition. This proves the non-linear nature of the transmission of fiscal policy. Fiscal policy has the same sign and is statistically significant. More specifically, it has a positive sign in the first regime corresponds to an output of less than $0.04 \%$ and a negative gap in the second regime. For other control variables, we find a strong asymmetric interaction between the output gap, dollarization, domestic credit and inflation.

The effect of dollarization is positive and statistically significant at the 5\% level of economic activity only when the economy is in recession. The coefficient of domestic credit is positive and statistically significant in the first regime which shows that domestic credit has a significant effect to stimulate growth in a recession. Finally, concerning the judgment variable capital, it has a statistically significant negative effect in a recession. This result is consistent with the literature, since these countries are independent of external resources to finance their growth.

\subsection{Case of Latin America}

Based on LM and Fisher tests, linearity is rejected only for the two transition variables delayed output gap and debt as a percentage of GDP (see table D in appendix).

Low critical value confirms the existence of high non-linearity between the output GAP and fiscal policy in Latin America. We keep debt as a percentage of GDP variable transition insofar as it has the lowest critical value $(0,050)$.

For this, we estimate our model with the transition variable. Thus, the results of LM and Fisher tests are used to detect the number of plans. Our results confirm the existence of a single threshold, which is suitable to capture the non-linearity of the fiscal policy. According to the results, there are effects of non-linearity of fiscal policy in 
Latin America. In the first regime, the coefficient on fiscal policy is negative.

The point where the activity switches from one regime to another is $55 \%$. $(=54.81 \%)$. This confirms that when the debt is less than a $55 \%$ rate, the budget deficit will have a positive effect. In other words, an expansionary fiscal policy will be beneficial to economic growth. However, this coefficient becomes positive in the second regime. This means when the debt exceeds $55 \%$, a restrictive fiscal policy will be recommended. This is consistent with the theory. Indeed, when the economy is in crisis, all macroeconomic variables have a negative effect on the activity. In particular, the judgment of sudden stops, inflation, changes in credit and dollarization increases the losses of the output.

Table 1. Results of estimation (PSTR) model: The case of Africa and Asia.

\begin{tabular}{lllll}
\hline Variables transition & Africa & GAP(-1) & & Asia \\
GAP(-1)
\end{tabular}

Source: Author's estimations. r: number regime, Numbers in parenthesis are t-student.

$*, * *, * * *$ respectively denote significance at the $10 \%, 5 \%$ and $1 \%$ levels.

\subsection{Case of Emerging Europe}

Table D (in appendix) presents the linearity test. It shows that the variable debt as a percentage of GDP variable rate is the most significant transition in explaining the non-linearity between fiscal policy and output GAP. Looking at the specific parameter fiscal policy, we find that the results are consistent with economic intuition. Indeed, the coefficient of the restrictive fiscal policy is negative in the first regime. This shows when the debt ratio is below $32 \%$ of GDP, the effect of the restrictive policy is significant and negative effect on the output GAP. However, an expansionary policy will have a positive effect on economic growth. Thus, the expansionary fiscal policy will be ineffective in the second regime where the growth rate exceeds the critical threshold.

The effect of the judgment of sudden stops is not clear in the first regime but becomes negative in the regime with a high debt ratio. Trade openness has a positive effect on economic growth for the two regimes. For inflation, when the debt ratio exceeds the critical threshold, inflation has a positive effect on economic growth. Regarding the increase in domestic credit, it is a positive sign in the regime to a high debt ratio. This shows that emerging Europe is mainly based on domestic credit to finance the activity.

Table 2. Results of estimation (PSTR) model: case of Latin America and Emerging Europe.

\begin{tabular}{|c|c|c|c|c|}
\hline Variables transition & $\begin{array}{l}\text { Latin America } \\
\text { Debt ratio }\end{array}$ & & $\begin{array}{l}\text { Emerging Europe } \\
\text { Debt ratio }\end{array}$ & \\
\hline $\mathrm{r}^{*}$ & 1 & & 1 & \\
\hline Location Parameters c & 54.820 & & 32.267 & \\
\hline Slopes Parameters $\gamma$ & 0.1364 & & 0.153 & \\
\hline fiscal Policy & -0.001 & $0.007 *$ & $-0.031 * * *$ & $0.038 * * *$ \\
\hline (restrictive) & $(-0.572)$ & $(1.652)$ & $(-9.003)$ & $(8.545)$ \\
\hline Sudden Stops & $\begin{array}{l}0.006 \\
(0.604)\end{array}$ & $\begin{array}{l}-0.074 * * \\
(-2.427)\end{array}$ & $\begin{array}{l}0.141^{* *} \\
(1.96)\end{array}$ & $\begin{array}{l}-0.176 * * \\
(-1.993)\end{array}$ \\
\hline Trade openness & $\begin{array}{l}0.001 * \\
(1.687)\end{array}$ & $\begin{array}{l}-0.001 * * * \\
(-2.687)\end{array}$ & $\begin{array}{l}0.0004 \\
(1.42)\end{array}$ & $\begin{array}{l}0.001 * * * \\
(1.772)\end{array}$ \\
\hline Inflation rate & $\begin{array}{l}0.0001 * * * \\
(3.180)\end{array}$ & $\begin{array}{l}-0.0001 * * * \\
(-3.07)\end{array}$ & $\begin{array}{l}-0.001 * * * \\
(-3.943)\end{array}$ & $\begin{array}{l}0.005 * * * \\
(3.828)\end{array}$ \\
\hline Variation of credit & $0.003 * * *$ & -0.002 & -0.001 & $0.005 * *$ \\
\hline
\end{tabular}




\begin{tabular}{lllll}
\hline Variables transition & $\begin{array}{l}\text { Latin America } \\
\text { Debt ratio }\end{array}$ & & $\begin{array}{l}\text { Emerging Europe } \\
\text { Debt ratio }\end{array}$ \\
\cline { 2 - 5 } & $(3.102)$ & $(-1.384)$ & $(-0.635)$ & $(2.474)$ \\
dollarisation & -0.0000 & -0.007 & $0.009^{* * *}$ & $-0.008^{* * *}$ \\
& $(-0.180)$ & -1.3660 & $(5.629)$ & $(-4.663)$ \\
American interest rate & $0.009 * * *$ & -0.001 & $0.008^{* *}$ & $-0.019^{* * *}$ \\
American GAP & $(4.879)$ & $(-0.422)$ & $(2.112)$ & $(3.083)$ \\
& $0.004^{* *}$ & -0.001 & $-0.024^{* * *}$ & $0.051^{* * *}$ \\
\hline
\end{tabular}

Source: Author's estimations. r: number regime, numbers in parenthesis are t-student.

$*, * * * * *$ respectively denote significance at the $10 \%, 5 \%$ and $1 \%$ levels.

\section{Discussion}

The objective of this paper is to determine the critical threshold for the expansionist policy becomes ineffective. To this end, our analysis was based on the model (PSTR) recently introduced by González and al. (2005).

This topic has been the subject of many economic debates. In our study, we have tried to provide some robust answers to some ambiguous question so far. We started first by testing the existence of non-linearity and determine the threshold number. Then, based on these results, we estimate the model (PSTR).

Expansionary fiscal policy is not systematically a barrier to investment and growth. Indeed, when the country is not indebted or in recession, the government intervention is needed to stimulate growth. However, after a certain threshold, the increase in public debt may hurt growth. Indeed, beyond this threshold, the chances of repayment and reduce the possibility of getting loans becomes difficult However, a simple linear estimate does not determine the threshold and does not allow studying the asymmetric effect of fiscal policy on economic growth.

In our study, promising new tracks can be addressed in order to further expand the topics discussed in this work. We propose two possible extensions.

The first is to further research on fiscal policy in emerging countries. Despite a number of studies, the question of the relative effectiveness of public spending and taxation remains a field of research still relatively unexplored regarding emerging countries. The study looked at a panel of countries rather than a single country. This gave us the opportunity to study individual behavior by observing the behavior of others, but it also allowed us to derive results on a large geographical area while taking into account individual heterogeneity between countries. In this context can enroll our second axis. We can focus our research by studying the question of the effectiveness of fiscal policy in major emerging countries. More specifically, we study these countries on an individual basis and we deepen our results by generating interpretations for each country. This allows us to draw the economic and financial characteristics relating to each emerging countries and compare them.

In this study, we focused on fiscal policy in general. The state has two levers to influence economic activity either reduces taxes or increase spending. Robustness appears in the study and comparison of the effectiveness of these two resources on economic activity.

This study may still be improved in terms of methodology. Indeed, the choice of threshold was determined by using the HP filter with a smoothing parameter 30 . One of the most critical is usually advanced in the use of the HP filter is the choice of the parameter value smoothing depends authors. It would be interesting to determine the optimal budget deficit, for which the expansionary fiscal policy cease to be effective not only for the different regions studied but also for each country in the region.

Finally, the study will be interesting to be compared with the methodology of Markov Switching Models Panel VAR approach developed by Kaufmann (2011) and Billio et al. (2013).

\section{Conclusion}

In this work, we study the effect of fiscal policy on economic growth in emerging countries during periods of economic instability. For this reason, our study used a new approach developed by González and al. (2005), the (PSTR) model. This model has been studied in 23 emerging countries grouped into four regions: Latin America, emerging Europe, Asia and Africa and covers the period 1990-2012.

This model takes into account the asymmetry in fiscal policy. The application of this model has been empirically confirmed by the test of linearity. The originality of our research is that we have not restricted to a single threshold variable. In addition to the output gap variable that represents the business cycle, we introduced other variable ie, the public debt ratio and the change in capital inflows.

This study derives several results. First, the nonlinearity of fiscal policy is explained by the phases of cycles and the level of public debt. The variable change in capital inflows did not appear to be relevant to explain the nonlinearity. Secondly, the behavior of fiscal policy differs depending on the threshold variable but it gave almost the same result for different regions studied.

Our results show that a state of crisis, when the output gap is below the threshold, the restrictive fiscal policy is more beneficial to economic recovery in emerging countries. In other words, state intervention when the economy is in crisis has resulted in aggravating the crisis. However, beyond this threshold, during the non-crisis 
expansionary fiscal policy is recommended. Our results do not support the idea that fiscal policy in emerging countries is counter-cyclical. We have also shown that fiscal policy is non-linear with the level of public debt.

The result indicates that the positive correlation between the budget deficit and the growth is associated with low public debt ratios, while for very high ratios of public debt, this correlation becomes negative.

In summary, this study allowed us to confirm the hypothesis that fiscal policy is pro-cyclical in periods of economic recession or when public debt is high. Which confirms the work of Aizenman and Jinjarak (2010), suggesting that initial conditions of public finances influence fiscal performance during the crisis.

Finally, according to our Search result, to implement policies to improve the fiscal and macroeconomic situation during non-crisis to reduce the risk of crises and to avoid

being faced with higher interest rates in periods of crises (Tavares and Valkanov (2001)). In this respect, these countries should pay particular attention to strengthening their financial institutions try to reduce political risk and improve the fiscal situation so that they can benefit from countercyclical fiscal policies.

\section{Acknowledgments}

We thank Pr. J.P, Allegret (University of Lyon-France) and Pr. F, Daboussi (University of Chiba-Japan) for their comments and suggestions.

JEL Classification: C23, E32, E62, G31, G32.

\section{Appendix}

Table A. The years of sudden stops, or large reversals in capital inflows.

\begin{tabular}{|c|c|c|c|c|c|c|c|}
\hline Latin America & & & & Asie & & & \\
\hline Brazil & & 2002 & 2009 & Chine, P.R.: Mainland & & 1998 & \\
\hline Chile & 1998 & 2008 & 2009 & Inde & 1995 & 2001 & 2009 \\
\hline Colombia & & 1998 & & Indonésie & 1997 & & \\
\hline Ecuador & & 1999 & & Coré & 1997 & 2008 & \\
\hline Mexico & & 1994 & 1995 & Malaisie & 1994 & 1997 & \\
\hline Uruguay & & 2002 & & Philippines & 1997 & 2009 & \\
\hline \multirow[t]{2}{*}{ Peru } & & 1998 & 1999 & Singapore & 2009 & & \\
\hline & & & & Thaïlande & 1997 & 2009 & \\
\hline Afrique & & & & Emerging Europe & & & \\
\hline Egypte & 1990 & & & Czech Republic & 1998 & 2008 & \\
\hline Sud Afrique & - & & & Estonia & 2008 & & \\
\hline \multirow[t]{3}{*}{ Tunisie } & - & & & Hungary & 1996 & 2009 & \\
\hline & & & & Polond & - & & \\
\hline & & & & Romania & 2009 & & \\
\hline
\end{tabular}

Source: Author's compilations and Honig (2006).

Table B. Linearity test case of Asia.

\begin{tabular}{|c|c|c|c|c|}
\hline & Capital inflow variation & Gap(-1) & Compte courant & Debt ratio \\
\hline \multirow{2}{*}{ Test LM } & 0,364 & 9,693 & 4,328 & 3,333 \\
\hline & $(0,546)$ & $(0,002)$ & $(0,037)$ & $(0,068)$ \\
\hline \multirow{2}{*}{ Test de Fisher } & 0,344 & 9,736 & 4,203 & 3,269 \\
\hline & $(0,558)$ & $(0,002)$ & $(0,042)$ & $(0,072)$ \\
\hline \multirow{2}{*}{ Test LRT } & 0,364 & 9,988 & 4,385 & 3,351 \\
\hline & $(0,547)$ & $(0,002)$ & $(0,038)$ & $(0,068)$ \\
\hline$r^{*}$ & 1 & 1 & 1 & 1 \\
\hline \multirow{2}{*}{ B0 } & $-0,0004$ & 0,0009 & $-0,009 * * *$ & $-0,049 * * *$ \\
\hline & $(-0,366)$ & $(0,877)$ & $(-4,393)$ & $(-9,2369)$ \\
\hline \multirow{2}{*}{ B1 } & 0,005 & $-0,03 *$ & $0,011 * * *$ & $0,05 * * *$ \\
\hline & $(1,097)$ & $(-2,698)$ & $(4,627)$ & $(9,1574)$ \\
\hline Location Parameters c & 24,258 & 0,07 & $-0,5929$ & 8,826 \\
\hline Slopes Parameters $\gamma$ & 97,627 & 205,974 & 33,437 & 0,969 \\
\hline
\end{tabular}

Source: Author's estimations. r: number regime, numbers in parenthesis are t-student. ***,*** respectively denote significance at the $10 \%, 5 \%$ and $1 \%$ levels.

\section{Definitions of Variables}

1. Growth rate: Log real GDP (in dollars based on 2000). 2. Budget deficit: The deficit of the Central Government as a percentage of GDP. 3. Public debt (\% of GDP). 4. Financial Account: The sum of direct investment with investment portfolios, financial derivatives and other investments. 5. Trade openness (\% of GDP (X+M) / GDP). 
6. Net capital flows (\% of GDP): Input capital in the form of direct investment and portfolio investment as a percentage of GDP + other investments (FDI Liabilities + portfolio equity liabilities + debt liabilities + derivatives liabilities).7. Output gap: the difference between actual GDP and potential GDP calculated with HP (Hodrick-Prescott (1980)). 8. Current balance of payments.

Table C. Linearity test case of Africa.

\begin{tabular}{|c|c|c|c|}
\hline & Capital inflow variation & Gap (-1) & Debt ratio \\
\hline \multirow{2}{*}{ Test LM } & 3,46 & 2,778 & 3,981 \\
\hline & $(0,063)$ & $(0,096)$ & $(0,046)$ \\
\hline \multirow{2}{*}{ Test de Fisher } & 3,427 & 2,721 & 3,980 \\
\hline & $(0,069)$ & $(0,104)$ & $(0,051)$ \\
\hline \multirow{2}{*}{ Test LRT } & 3,564 & 2,841 & 4,112 \\
\hline & $(0,064)$ & $(0,097)$ & $(0,047)$ \\
\hline $\mathrm{r}^{*}$ & 1 & 1 & 1 \\
\hline \multirow{2}{*}{ B0 } & $-0,009 * * *$ & 0,001 & $-0,012 * * *$ \\
\hline & $(-5,096)$ & $(-0,173)$ & $(-5,855)$ \\
\hline \multirow{2}{*}{ B1 } & $0,01 * * *$ & $-0,004 * *$ & $0,012 * * *$ \\
\hline & $(5,240)$ & $(2,421)$ & $(5,642)$ \\
\hline Location Parameters c & $-14,527$ & 3,359 & 29,079 \\
\hline Slopes Parameters $\gamma$ & 0,205 & 366,326 & 32,034 \\
\hline
\end{tabular}

Source: Author's estimations. r: number regime, numbers in parenthesis are t-student. *,**,** respectively denote significance at the $10 \%, 5 \%$ and $1 \%$ levels.

Table D. Linearity test case of Latin America.

\begin{tabular}{|c|c|c|c|}
\hline & Capital inflow variation & Gap (-1) & Debt ratio \\
\hline \multirow{2}{*}{ Test LM } & 0,043 & 2,963 & 3,836 \\
\hline & $(0,836)$ & $(0,085)$ & $(0,050)$ \\
\hline \multirow{2}{*}{ Test de Fisher } & 0,040 & 2,859 & 3,724 \\
\hline & $(0,842)$ & $(0,093)$ & $(0,056)$ \\
\hline \multirow{2}{*}{ Test LRT } & 0,043 & 2,993 & 3,887 \\
\hline & $(0,836)$ & $(0,086)$ & $(0,051)$ \\
\hline $\mathrm{r}^{*}$ & 1 & 1 & 1 \\
\hline \multirow{2}{*}{ B0 } & $-0,0002$ & $0,129 * * *$ & $-0,0003$ \\
\hline & $(-0,173)$ & $(10,460)$ & $(-0,339)$ \\
\hline \multirow{2}{*}{ B1 } & $0,005 * *$ & $-0,129 * * *$ & $0,008 * * *$ \\
\hline & $(2,421)$ & $(-10,236)$ & $(3,417)$ \\
\hline Location Parameters c & 2,915 & $-0,091$ & 50,839 \\
\hline Slopes Parameters $\gamma$ & 2,212 & 84,926 & 558,913 \\
\hline
\end{tabular}

Source: Author's estimations.

$\mathrm{r}$ : number regime, numbers in parenthesis are $\mathrm{t}$-student

$*, * *, * * *$ respectively denote significance at the $10 \%, 5 \%$ and $1 \%$ levels.

Table E. Linearity test case of Emerging Europe.

\begin{tabular}{|c|c|c|c|}
\hline & Capital inflow variation & Gap (-1) & Debt ratio \\
\hline Test LM & $\begin{array}{c}0,077 \\
(0,781)\end{array}$ & $\begin{array}{c}6,913 \\
(0,009)\end{array}$ & $\begin{array}{c}8,221 \\
(0,004)\end{array}$ \\
\hline Test de Fisher & $\begin{array}{c}0,072 \\
(0,790)\end{array}$ & $\begin{array}{c}6,994 \\
(0,010)\end{array}$ & $\begin{array}{c}8,461 \\
(0,005)\end{array}$ \\
\hline Test LRT & $\begin{array}{c}0,077 \\
(0,782)\end{array}$ & $\begin{array}{c}7,210 \\
(0,009)\end{array}$ & $\begin{array}{c}8,651 \\
(0,004)\end{array}$ \\
\hline $\mathrm{r}^{*}$ & 1 & 1 & 1 \\
\hline B0 & $\begin{array}{c}0,009 \\
(1,099)\end{array}$ & $\begin{array}{c}0,012 \text { *** } \\
(4,666)\end{array}$ & $\begin{array}{l}-0,022 * \\
(-4,646)\end{array}$ \\
\hline B1 & $\begin{array}{c}-0,012 \\
(-1,623)\end{array}$ & $\begin{array}{c}-0,017 * * * \\
(-4,282)\end{array}$ & $\begin{array}{l}0,022 * \\
(5,406)\end{array}$ \\
\hline Location Parameters c & $-8,844$ & $-0,020$ & 35,218 \\
\hline Slopes Parameters $\gamma$ & 120,871 & 45,919 & 39,852 \\
\hline
\end{tabular}

Source: Author's estimations.

r: number regime, numbers in parenthesis are t-student

$*, * *, * * *$ respectively denote significance at the $10 \%, 5 \%$ and $1 \%$ levels. 


\section{References}

[1] Afonso A., Grüner H. P. \& Kolerus, C. [2010]. Fiscal Policy and Growth: do Financial Crises Make a Difference?. WP Series 1217, European Central Bank.

[2] Aizenman J, \& Jinjarak Y [2010]. De Facto Fiscal Space and Fiscal Stimulus: Definition and Assessment. NBER WP/16539.

[3] Aghevli B.B. [1999]. The Asian Crisis Causes and Remedies. Finances and Development, IMF, Volume 36, N².

[4] Billio, Monica \& Casarin, Roberto and Ravazzolo, Francesco and van Dijk, H. K., (2013). Interactions between Euro zone and US Booms and Busts: A Bayesian Panel Markov-Switching VAR Model. Norges Bank Working Paper 20.

[5] Blanchard O. \& Perotti R. [2002]. An Empirical Characterization of Dynamic Effects of Changes in Government Spending and Taxes on Output. Quarterly Journal of Economics, 117, p. 1329-368.

[6] Baldacci E., Gupta S. \& Mati A. [2008]. Is It Still Mostly Fiscal? Determinants of Sovereign Spreads in Emerging Markets. IMF Working Paper 08/259.

[7] Bouthevillain C. \& Dufrénot G. [2010]. Are the Effects of Fiscal Changes Different in Times of Crisis and Non-crisis? The French Case. Working papers 286, Banque de France.

[8] Fok, D., van Dijk, D. \& Franses, P. [2005]. A multi-level Panel STAR Model for US Manufacturing Sectors. Journal of Applied Econometrics 20, 811-827.

[9] Fouquau J., Hurlin C. \& Rabaud I. [2007]. The Feldstein-Horioka Puzzle: A Panel Smooth Transition Regression Approach. WP halshs-00156688, HAL.

[10] Gavin M., Perotti R. \& Talvi E. [1996]. Managing Fiscal Policy in Latin America: Volatility, procyclicality and Limited Creditworthiness. Washington DC: Inter-American Development Bank.

[11] Gavin M. \& Perotti R. [1997]. Fiscal Policy in Latin America.
NBER Macroeconomics Annual.

[12] Giavazzi F., Jappelli T.,Pagano \& Benedetti M. [2005]. Searching for Non-monotonic Effects of Fiscal Policy: New Evidence, Monetary and Economic Studies. Special Edition, 197-231.

[13] González A., Terasvirta T. \& Van Dijk, D. [2005]. Panel Smooth Transition Regression Models. SSE/EFI Working Paper Series in Economics and Finance, No. 604.

[14] González-Hermosillo B. \& Hesse H. [2009]. Global Market Conditions and Systemic Risk. IMF Working Paper 09/230.

[15] Hansen, B.E. [1999]. Threshold Effects in Non-Dynamic Panels: Estimation, Testing, and Inference. Journal of Econometrics 93, 334-368.

[16] Honig A. [2006]. A model of Liability Dollarization and Myopic Governments. International Economic Journal, Korean International Economic Association, Vol. 203, p 343-355.

[17] Hutchison M. M., Noy I. \& Wang L. [2010]. Fiscal and Monetary Policies and the Cost of Sudden Stops. Journal of International Money and Finance, Vol. 296, p973-987.

[18] Jawadi F., Mallick S. K. \& Sousa R.M. [2011]. Fiscal Policy in the BRICs. NIPE WP 19 -Universidade do Minho.

[19] Kaufmann, S. (2011). K-state Switching Models with Endogenous Transition Distribution. Swiss National Bank, Working Paper 2011-13.

[20] Kirchner M., Cimadomo J. \& Hauptmeier S. [2010]. Transmission of Government Spending Shocks in the Euro Area: Time Variation and Driving forces. ECB WP, 1219.

[21] Philip R. Lane \& Gian Maria Milesi-Ferretti [2007]. The External Wealth of Nations Mark II: Revised and Extended Estimates of Foreign Assets and Liabilities, 1970-2004", Journal of International Economics 73, November, 223-250.

[22] Reinhart, C, M. \& Rogoff, K [2010]. From Financial Crash to Debt Crisis. NBER WP/15795

[23] Tavares J. \& Rossen V., [2001]. The Neglected Effect of Fiscal Policy on Ptock and Bond Returns. FEUNL WP Series 413, Universidade Nova de Lisboa, Faculdade de Economia. 